Ekuitas: Jurnal Pendidikan Ekonomi

Volume 7, Number 2, 2019, 68-74

P-ISSN : 2354-6107 E-ISSN : 2549-2292

Open Access: https://ejournal.undiksha.ac.id/index.php/EKU

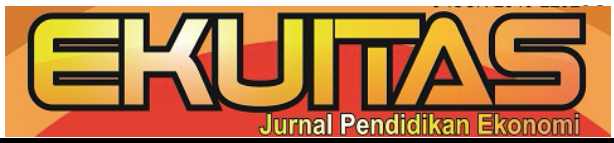

\title{
ANALISIS KESULITAN GURU SMA DALAM PELAKSANAAN PEMBELAJARAN EKONOMI AKUNTANSI BERDASARKAN KURIKULUM 2013 DI PROPINSI RIAU
}

\author{
Sukarni ${ }^{1 *}$, Ulfa Rahmadani ${ }^{2}$, Mulgaidah ${ }^{3}$ \\ 1,2,3Prodi Pendidikan Akuntansi FKIP UIR, Pekanbaru - Indonesia
}

\section{A R T I C L E I N F O}

Article history:

Received 12 Mei 2019

Received in revised form 12 Juny 2019

Accepted 05 December 2019

Available online 11

December 2019

Kata Kunci:

Kesulitan Guru,

Pembelajaran Ekonomi

Kurikulum 2013

Keywords:

Difficulties, Economic

Learning, 2013 Curriculum

\begin{abstract}
A B S T R A K
Penelitian ini bertujuan untukmengetahui dimensi apa yang paling menyulitkan guru dalam pembelajaranekonomi berdasarkan Kurikulum 2013 di propinsi Riau.Penelitian ini merupakan penelitian deskriptif dengan pendekatankuantitatif.Populasi penelitian adalah guru-guru Ekonomi Akuntansi di propinsi Riau yang tergabung dalam MGMP di masing-masing Kabupaten /Kota yaituberjumlah 690 orang, dan sample diambil berpedoman pada table Krejcie dan Morgan (1970), diperoleh jumlah sampel 248. orang. Tekhnik sampling digunakan adalah Stratified Random Sampling. Teknik pengumpulan data adalah angket.Ujivaliditas menggunakan rumus Product Moment dari Pearson dan uji reliabilitasmenggunakan model Cronbach's Alpha. Teknik analisis data adalah analisis statistik-deskriptif yang kemudian diinterprestasikan kedalambentuk presentase. Hasil penelitian ini yaitu umumnya di provinsi Riau guru ekonomi akuntansi berada pada kategori "sulit". Sedangkan untuk dimensi perencanaan 9 dari 11 kabupaten/kota berada pada kategori "sulit", sedang satu berada pada kategori "sulit sekali" yaitu kabapaten Indragiri Hulu" dan satu kabupaten/kota berada pada kategori "cukup sulit" yaitu Pekanbaru dan yang berada pada kategori "tidak sulit" adalah "rokan hilir".Dimensi perencanaan, pembuatan RPP berdasarkan silabusmerupakan hal yang sangat sulit bagi guru ekonomi akuntansi .
\end{abstract} Dimensi pelaksanaan yang masuk dalam kategori "sulit" yaitu (1) Penerapan 5M dalam proses pembelajaran, (2) Merancang media untuk pembelajara 5M, (3) Mencari dan Penerapan model pembelajaran, (4) Penggunaan media belajar cetak/elektronik dan (5) Mengajak siswa untuk berfikir tingkat tinggi. Dimensi penilaian berada pada kategori "sangat sulit" yaitu (1) penilaian afektif dan (2) mengukur kemampuan berdasarkan HOTS sedang 6 lainya berada pada kategori "sulit"

\section{A B S T RAC T}

This study aims to determine what dimensions are most difficult for teachers in economic learning based on the 2013 curriculum in Riau province. This research is a descriptive study with a quantitative approach. The study population was Economics Economics teachers in Riau province who were members of the MGMP in each Regency / City, amounting to 690 people, and samples were taken based on Krejcie and Morgan's table (1970), obtained a sample of 248. people. The sampling technique used is Stratified Random Sampling. Data collection technique is a questionnaire. The validity test uses the Product Moment formula from Pearson and the reliability test uses the Cronbach's Alpha model. Data analysis technique is a statisticaldescriptive analysis which is then interpreted into a percentage form. The results of this study are generally in the province of Riau accounting economics teacher is in the category of "difficult". While for the planning dimensions 9 out of 11 regencies / cities are in the "difficult" category, while one is in the "very difficult" category, namely Indragiri Hulu Kabapaten and one district / city is in the "quite difficult" category, which is Pekanbaru and which is in the category "Not difficult" is "downstream rokan". The planning dimension, making lesson plans based on the syllabus is very difficult for accounting economics teachers.

\footnotetext{
* Corresponding author.

E-mail : sukarnifkipuir@edu.uir.ac.id (Sukarni) $\underline{10.23887 / e k u i t a s . v 7 i 2.21180}$
} 
Implementation dimensions included in the category of "difficult" namely (1) Application of 5M in the learning process, (2) Designing media for 5M learning, (3) Finding and applying learning models, (4) Use of print / electronic learning media and (5) Invite students to think at a high level. The dimensions of the assessment are in the category of "very difficult" namely (1) affective assessment and (2) measuring abilities based on HOTS while the other 6 are in the category of "difficult"

Copyright (c) Ekuitas: Jurnal Pendidikan Ekonomi. All rights reserved.

\section{Pendahuluan}

Kurikulum pendidikan di Indonesia sudah sering terjadi perubahan, mulai sejak zaman awal kemerdekaan sampai pada zaman reformasi. Setiap kurikulum sesuai dengan zamannya, karena setiap zaman itu mempunyi prioritas dan tuntutan masing masing. Sehingga tidak dapat disalahkan pemerintah yang selula memenuhi tuntutan masyarakat lokal, regional sampai pada masyarakat internasional. Sehingga tidak dapat dikatakan kurikulum lama itu jelek dan kurikulum sekara tidak jelek, karena masing masing kurikulum harus dapat menjawab kebutuhan masyarakatnya.

Tahun 2013 pemerintah mengmbil langkah untuk memperbaharui kurikulum, tentu saja ini juga untuk memenuhi tuntutan masyarakat dan dicanangkanlah pergantian kurikulum pendidikan Indonesia.Kurikulum Tingkat Satuan Pendidikan (KTSP) diganti dengan Kurikulum 13 (K13) meskipun baru tahun 2015 di uji cobakan. K13 mengalami revisi beberapa kali yaitu th 2016 dan 2017.

Dasar hukum pelaksanaan atau pedoman pelaksanaan K13 oleh guru yaitu dengan keluarnya Kepmendikbud No 20 th 2016, No 21 th 2016, No 22 th 2016 dan No 23 th 2016. Kepmendikbud No 20 th 2016 mengatu tentang standar kelulusan. Ada tiga dimensi yang diatur dalam Kepmendibud No 20/2016 yaitu dimensi sikap, dimensi pengetahuan dan dimensi ketrampilan.

Permendikbud no 22/16 tentang proses yaitu yang mengatur proses pembelajaran mulai dari aspek perencanaan, aspek pelaksanaan serta aspen penilaian. Pada aspek ini banyak dijumpai masalah guru karena Permendikbud no 21/16 mengatur hal hal yang operasinal dikerjakan guru.

Secara ideal semua guru sudah harus dapat melaksanakan permendibud ini karena sudah banyak usaha pemerintah agar guru memehami implementasi K13. Sudah seharusnya guru mampu membuat perangkat pebelaran dengan baik karena dalam Permendikbud no 21/16 diberikan acuan yang tegas tantang tata cara menyusun perangkat pembelajaran.

Namun kenyataan dilapangan berdasarkan pengamatan peneliti serta wawancara informal yang peneliti lakukan masih banyak guru mengeluh tentang penyusunan perangkat sertra melaksanakan proses pembelajan termasuk juga penilaian. Keluhan guru umumnya menyampaikan kesulitan dan ketidak pahaman mereka dengan perangkat pembelajaran seperti susahnya menerjemhan Kompetensi Inti dan Kompetensi Dasar kedalam Indikator pencapaian. Sulitnya menerapkan pembelajaran santifik karena kebiasaan anak dan kurangnya sarana serta banyak form penilaian yang harus mereka kerjakan.

Berbagai permasalahan yang terjadi dilapangan seperti belum tersedianya buku paket untuk murid maupun pegangan guru dan minimnya kesiapan guru dalam menerapkan Kurikulum 2013 karena belum mendapatkan pelatihan. Demikian pula isu isu yang jadi perbincangan diantara guru yaitu dengan keluarnya Kepmen N0 20, 21,22, 23 tahun 2016 tentang revisi kurikulum 2013 sehingga juga menjadikan kabingungan pada guru.

Penelitian yang dilakukan oleh Anna Silviana Muslimah (2015) yang berjudul "Analisis Kesulitan Guru SMA dalam Pembelajaran Ekonomi Bersarkan Kurikulum 13 di MGMP Sekapaten Sleman". Hasil penelitian ini menunjukkan bahwa guru SMA di Kabupaten Sleman kesulitan dal aspek penilaian pembelajaran dengan ketegori kesulitanya "cukup sulit". Begitu juga dengan penelitian Ivan Prasetyo (2015) yang berjudul "hambatan hambatan pelkanaan kuriklum 13 di SMK 1 Sragen Yokyakarta". Hasil penelitian menunjukkan bahwa hambatan yang dialami guru guru SMK Sragen aalah (1) perencanaan pembelajaran yang masuk dalam kategori cukup banyak hambatan dengan skor 13,5, (2) hambatan kedua dilihat dari pelaksaan proses pembelajaran dengan skor 13 termasuk kategori cukup banyak hamabata juga, (3) hambata ketiga dilihat dari pelaksanaan evaluasi hasil pembelajaran dengan skor 13, 43 masuk dalam kategori cukup banyak kesulitan.

Penelitian ini mempunai perbedaan dari segi rumusan masalah, tujuan yang di gunakan dan subjek penelitian yaitu untuk mengetahui dimensi mana yang dominan dialami guru ekonomi akuntansi dalam penerapan K13. Kontribusi yang di dapat dari penelitian ini adalah bahwasannya guru ekonomi akuntansi masih sangat perlu diberikan pelatihan dan pendampingan dalam melaksana.kan K13 di sekolahnya. 


\section{Metode}

Penelitian ini menggunakan metode deskriptif kuatitatif. Pendekatan deskriptif kuantitatif digunakan untuk untuk mendiskripsikan data dari angket yang telah disebarkan pada guru Ekonomi SMA se Propinsi Riau sebagai responden; penelitian ini.

Populasi adalah wilayah generalisasi yang terdiri atas: objek/subjek yang mempunyai kualitas dan karakteristik tertentu yang ditetapkan oleh peneliti untuk dipelajari dan kemudian ditarik kesimpulannya (Sugiyono, 2013: 117). Populasi dalam penelitian ini adalah semua guru ekonomi yang tergabungdalam MGMP Ekonomi di Propinsi Riau sejumlah 690 guru.

Sampel penelitian diambil dengan berpedoman pada table Krejcie dan Morgan (1970). Sehingga diperoleh jumlah sampel 246.orang. Kemudian tekhnik sampling yang digunakan adalah Stratified Random Sampling untuk mengurangi pengaruh faktor heterogen dan melakukan pembagian elemen-elemen populasi ke dalam strata.

Data akan diolah menggunakan distribusi frekuensi dengan pendekatan sturges. Awalnya data akan dikategorikan kedalam empat kategori.

Berdasarkan rumus tersebut maka diperoleh hasil pengkategorian seperti berikut.

Table 1. Kategori Penilaian

\begin{tabular}{|l|l|}
\hline Interval & Kategori \\
\hline $1,0-1,74$ & Tida sulit \\
\hline $1,75-2,49$ & Cukup sulit \\
\hline $2,50-3,24$ & Sulit \\
\hline $3,25-4$ & Sangat sulit \\
\hline
\end{tabular}

Pengkategorian kesulitan berdasarkan pengujian menurut Saifudin Azwar (2013:147) memiliki tujuan untuk menempatkan individu ke dalam kelompok-kelompok yang posisinya berjenjang menurut suatu kontinum berdasar atribut yang diukur.

Tabel 2. Kriteria Hambatan Pembelajaran dalam Pelaksanaan Kurikulum.

\begin{tabular}{|l|l|}
\hline Kategori & Rentang \\
\hline Sangat Sulit & $>\mathrm{X}+2 \mathrm{SD}$ \\
\hline Sulit & $\mathrm{X}+\mathrm{SD}-\mathrm{X}+$ 2SD \\
\hline Cukup Sulit & $\mathrm{X}-(\mathrm{X}+\mathrm{SD})$ \\
\hline Sedikit & $(\mathrm{X}-\mathrm{SD})-\mathrm{X}$ \\
\hline Sangat Sedikit & $<\mathrm{X}-\mathrm{SD}$ \\
\hline
\end{tabular}

\section{Hasil dan pembahasan}

Gambaran mengenai tingkat kesulitan guru dalam pembelajaran ekonomi akuntansi di provinsi Riau dalam pelaksanaan pembelajaran berdasarkan Kurikulum 2013. Tingkat kesulitan tersebut diukur dengan angket yang berjumlah 25 butir pertanyaan. Tingkat kesulitan implementasi kurikulum 13 dilihat dari tiga dimensi yaitu (a) perensanaan, (b) pelaksanaan dan (c) penilaian

1) Dimensi Perencanaan

Berdasarkan hasil perhitungan statistic diskriptif dengan pendekatan sturges dapat dikelompokkan kesulitan guru dalam pelaksanaan kurikulum 13, seperti terlihat pada table 4.34.

.Table 3 : Kategori kesulitan guru Ekonomi Akuntansi dalam Perencanaan Kurikulum 13 se Propinsi Riau.

\begin{tabular}{|l|l|l|l|}
\hline No & Indikator & $\begin{array}{l}\text { Skor rata } \\
\text { rata }\end{array}$ & Kategori \\
\hline 1 & Pembuatan RPP berdasarkan silabus & 3.51 & SS \\
\hline 2 & Perumusan Indikator berdasarkan KI dan KD & 2.47 & CS \\
\hline 3 & Perumusan tujuan pembelajaran & 2.34 & CS \\
\hline 4 & Perumusan dan pemilihan materi ajar & 2.43 & CS \\
\hline
\end{tabular}




\begin{tabular}{|l|l|l|l|}
\hline 5 & $\begin{array}{l}\text { Merumuskan indicator dan tujuan berdasarkan } \\
\text { kemampuan berfikir HOTS }\end{array}$ & 3.04 & $\mathrm{~S}$ \\
\hline 6 & Persiapan/pemilihan media pembelajaran & 2.41 & $\mathrm{CS}$ \\
\hline 7 & Perumusun perencanaan model pembelajaran & 2.73 & $\mathrm{~S}$ \\
\hline 8 & Perumusan penilaian pembelajaran berfikir HOTS & 3.02 & $\mathrm{~S}$ \\
\hline 9 & Mendesain pembelajaran yang berorientasi HOTS & 2.63 & $\mathrm{~S}$ \\
\hline
\end{tabular}

Pada aspek perencanaan ini guru ekonomi akuntansi, dari 9 pertanyaan yang diajukan 4 pertanyaan dijawab dengan sulit dan cukup sulit sedangkan satu pertanyaan dijawab dengan sangat sulit. Dari jawaban angket tentang dimensi perencanaan, ternyata tidak satupun yang menyakan mudah.

Selanjutnya, penganalisaan data berdasarkan statistic diskriptif gunana menetahui dan menempatkan individu ke dalam kelompok-kelompok yang posisinya berjenjang menurut suatu kontinum berdasar atribut yang diukur. Pada dimensi perencanaan untuk guru guru ekonomi akuntansi se Propinsi Riau yang dijelaskan melalui table 4.

Table 4. Kategori Kesulitan Guru Ekonomi Akuntansi dalam Mengimplentasikan Kurikulum 13 dari Dimensi Perencanaan se Provinsi Riau

\begin{tabular}{|l|l|l|l|l|}
\hline No & Kategori & Rentang & F & $\%$ \\
\hline 1 & Sangat Sulit & $>37$ & 18 & 7.26 \\
\hline 2 & Sulit & 30 s.d 36 & 13 & 5.24 \\
\hline 3 & Cukup Sulit & 24 s.d 29 & 145 & 58.47 \\
\hline 4 & Tidak Sulit & 17 s.d 23 & 42 & 16.94 \\
\hline 5 & Sangat Mudah & $<16$ & 30 & 12.10 \\
\hline & Jumlah & & 248 & 100 \\
\hline
\end{tabular}

Dari table 4 diatas terlihat kesulitan guru ekonmi Akuntansi dalam melaksanakan kurikulum 13 pada aspek/dimensi perencanaan setelah dikategorikan maka terlihat bahwa guru ekonomi akuntansi cukup sulit $59 \%$, tidak sulit $17 \%$, sangat mudah $12 \%$ sedangkan yang tergolong sangt sulit $7 \%$ dan dan sulit $5 \%$.

2) Dimensi pelaksanaan

Dimensi pelaksanaan akan di ukur dengan 8 sub indicator yang dituangkan dalam angket. Dari 8 pernyataan tersebut setelah dicri skor rata rata selanjutnya di kelompokan mejadi 4 kategori, hasilnya dijelaskan pada table 5 .

Tebel 5. Kategori kesulitan guru Ekonomi Akuntansi dalam Pelaksanaan Kurikulum 13 se Propinsi Riau.

\begin{tabular}{|l|l|l|l|}
\hline No & Indikator & $\begin{array}{l}\text { Skor rata } \\
\text { rata }\end{array}$ & Kategori \\
\hline 1 & Penerapan 5M dalam proses pembelajaran & 2.81 & S \\
\hline 2 & Merancang media untuk pembelajara 5M & 2.99 & S \\
\hline 3 & Penyampaian bahan ajar & 2.74 & CS \\
\hline 4 & Mencari dan Penerapan model pembelajaran & 2.34 & S \\
\hline 5 & Penggunaan media belajar cetak/elektronik & 2.87 & S \\
\hline 6 & Pengelolaan kelas & 2.58 & CS \\
\hline 7 & Mengajak siswa untuk berfikir tingkat tinggi & 2.32 & S \\
\hline 8 & Mengajak siswa untuk aktif & 2.67 & CS \\
\hline
\end{tabular}

Berdasarkan table 5 diatas terlihat bahwa dari 8 subindikator yang ditanyakan kepada guru ekonomi akuntansi se Privinsi Riau 5 diataranya masuk dalam kategori "sulit" yaitu (1) Penerapan 5M dalam proses pembelajaran, (2) Merancang media untuk pembelajara 5M, (3) Mencari dan Penerapan model pembelajaran, (4) Penggunaan media belajar cetak/elektronik dan (5) Mengajak siswa untuk berfikir tingkat tinggi. Sedangkan 3 subindikator dinyatan "cukup sulit" yaitu (1) Penyampaian bahan ajar, (2) Pengelolaan kelas dan (3) Mengajak siswa untuk aktif.Analisi s statiktik diskriptif memperlihatkan hasil seperti table 6 dibawah ini. 
Table 6. Kategori Kesulitan Guru Ekonomi Akuntansi dalam Mengimplentasikan Kurikulum 13 dari Dimensi Pelaksanaan se Provinsi Riau

\begin{tabular}{|l|l|l|l|l|}
\hline No & Kategori & Rentang & F & $\%$ \\
\hline 1 & Sangat Sulit & $>33$ & 11 & 4.44 \\
\hline 2 & Sulit & 27 S.D 32 & 20 & 8.06 \\
\hline 3 & Cukup Sulit & 21 S.D 26 & 122 & 49.19 \\
\hline 4 & Tidak Sulit & 17 S.D 20 & 44 & 17.74 \\
\hline 5 & Sangat Mudah & $<16$ & 51 & 20.56 \\
\hline & & & 248 & 100 \\
\hline
\end{tabular}

Berdasarkan table 6 diatas terlihat bahwa dalam pelaksanaan kurikulum 13 guru ekonomi akuntansi se Provisi Riau "cukup sulit" ini terlihat dari pernyataan dari angket yang diedarkan. Hasil angket memperlihatkan 49\% tergolong dalam kategori cukup sulit dan yang terkelompok dalam ketegori sangat mudah $21 \%$ dan tidak sulit 18\%, sedangkan yang masuk kategori sulit ada 8\% dan sangat sulit ada $4 \%$.

3) Dimensi Penilaian

Dimensi penilaian akan di ukur dengan 8 sub indicator yang dituangkan dalam angket. Dari 8 pernyataan tersebut setelah dicri skor rata rata selanjutnya di kelompokan mejadi 4 kategori, hasilnya dijelaskan pada table 7 .

Tebel 7. Kategori kesulitan guru Ekonomi Akuntansi dalam Penilaian Kurikulum 13 se Propinsi Riau.

\begin{tabular}{|l|l|l|l|}
\hline No & Indikator & $\begin{array}{l}\text { Skor rata } \\
\text { rata }\end{array}$ & Kategori \\
\hline 1 & Penilaian afektif & 3.09 & SS \\
\hline 2 & Penilaian kognitif & 2.75 & $\mathrm{~S}$ \\
\hline 3 & Penilaian psikomotorik & 2.73 & $\mathrm{~S}$ \\
\hline 4 & Mengukur kemampuan berdsarkan HOTS & 3.13 & $\mathrm{SS}$ \\
\hline 5 & Menilai secara individu/kelompok & 2.80 & $\mathrm{~S}$ \\
\hline 6 & Menilai secara detail lengkap dan meyeluruh & 2.93 & $\mathrm{~S}$ \\
\hline 7 & Mengolah/merekapitulasi nilai & 2.88 & $\mathrm{~S}$ \\
\hline 8 & Mengisi daftar penilaian & 2.81 & $\mathrm{~S}$ \\
\hline
\end{tabular}

Berdasarkan table 7 diatas tergambar bahwa dari 8 sub indicator yang di tanyakan kepafa responden dua beraa pafa kategori "sangat sulit" yaitu (1) penilaian afektif dan (2) mengukur kemampuan bersarkan HOTS sedang 6 lainya berada paa kategori "sulit" yaitu (1) Penilaian kognitif, (2) Penilaian psikomotorik, (3) Menilai secara individu/kelompok, (4) Menilai secara detail lengkap dan meyeluruh, (5) Mengolah/merekapitulasi nilai dan (6) Mengisi daftar penilaian.

Sedangkan, penganalisaan data berdasarkan statistic diskriptif guna mengetahui dan menempatkan individu ke dalam kelompok atau kategori dimana .Pada dimensi penilaian untuk guru guru ekonomi akuntansi se Propinsi Riau yang dijelaskan melalui table 8

Table 8 : Kategori Kesulitan Guru Ekonomi Akuntansi dalam Mengimplentasikan Kurikulum 13 dari Dimensi Penilaian se Provinsi Riau

\begin{tabular}{|l|l|l|l|l|}
\hline No & Kategori & Rentang & F & $\%$ \\
\hline 1 & Sangat Sulit & $>37$ & 2 & 0.81 \\
\hline 2 & Sulit & 30 S.D 36 & 25 & 10.08 \\
\hline 3 & Cukup Sulit & 24 S.D 29 & 100 & 40.32 \\
\hline 4 & Tidak Sulit & 17 S.D 23 & 64 & 25.81 \\
\hline 5 & Sangat Mudah & $<16$ & 57 & 22.98 \\
\hline & & & 248 & 100.00 \\
\hline
\end{tabular}


Berdasarkan tabel 8 diatas terlihat bahwa dalam pelaksnaan kurikulum 13 guru ekonomi akuntansi se Provisi Riau pada dimensi penilaian "cukup sulit". Hal ini terlihat dari pernyataan dari angket yang diedarkan. Hasil angket memperlihatkan 40\% tergolong dalam kategori cukup sulit dan yang terkelompok dalam ketegori tidak sulit 25\% dan sangat mudah $23 \%$, sedangkan yang masuk kategori sulit ada $10 \%$ dan sangat sulit ada $1 \%$.

Rekapitulasi dari data yang di jelaskan diatas seperti terlihat pada table 9.

Tabel 9. Rekapitulasi Kategori Kesulitan Guru Ekonomi Akuntansi

\begin{tabular}{|l|l|c|c|c|c|c|c|}
\hline No & Kabupaten/Kota & \multicolumn{2}{|c|}{ Perencanaan } & \multicolumn{2}{c|}{ pelaksanaan } & \multicolumn{2}{c|}{ Penilaian } \\
\hline & & Skor & Kategori & Skor & Kategori & Skor & Kategori \\
\hline 1 & Pekanbaru & 1.97 & CS & 2.02 & CS & 1.81 & CS \\
\hline 2 & Rokan Hilir & 1.64 & TS & 1.86 & CS & 1.88 & CS \\
\hline 3 & Bengkalis & 2.48 & S & 2.25 & CS & 2.67 & S \\
\hline 4 & Rokan Hulu & 2.70 & S & 2.66 & S & 3.30 & SS \\
\hline 5 & Indragiri Hulu & 3.71 & SS & 3.60 & SS & 3.60 & SS \\
\hline 6 & Indraguri Hilir & 2.71 & S & 2.90 & S & 2.77 & S \\
\hline 7 & Kampar & 3.09 & S & 3.08 & S & 3.30 & S \\
\hline 8 & Pelalawan & 2.73 & S & 2.87 & S & 2.66 & S \\
\hline 9 & Siak & 2.72 & S & 2.91 & S & 2.78 & S \\
\hline 10 & Meranti & 2.68 & S & 2.70 & S & 3.23 & S \\
\hline 11 & Dumai & 2.77 & S & 2.77 & S & 3.12 & S \\
\hline
\end{tabular}

Keterangan: $\mathrm{CS}=$ cukup sulit, $\mathrm{SS}=$ sangat sulit, $\mathrm{S}=$ sulit, $\mathrm{TS}=$ tidak sulit

Pengkategorian data diolah menggunakan distribusi frekuensi dengan pendekatan sturges, yang mengkategorikan kedalam empat kategori, yaitu (1) tidak sulit, (2) cukup sulit, (3) sulit dan (4) sangat sulit. Pengkategorian ini dilakukan menggunakan rumus skor rata-rata. Dari table 9 diatas tergambar bahwa umumnya di provinsi Riau guru ekonomi akuntansi berada pada kategori "sulit", seperti terlihat pada kategori perencanaan 9 dari 11 kabupaten/kota berada pada kategori "sulit" sedang satu berada pada kategori "sulit sekali" yaitu kabapaten Indragiri Hulu" dan satu kabupaten/kota berada pada kategori "cukup sulit" yaitu Pekanbaru dan yang berada pada kategori "tidak sulit" adalah "rokan hilir".

Berdasarkan hasil perhitungan statistic diskriptif dengan pendekatan sturges dapat dikelompokkan kesulitan guru dalam implementasi kurikulum 13, pada dimensi perencanaan dapat dijelaskan sebagai beriut. Dari 9 sub indicator, satu atau pembuatan RPP berdasarkan silabus merupakan hal yang sangat sulit bagi guru ekonomi akuntansi di Provinsi Riau.Selanjutnya (a) merumuskan indicator dan tujuan berdasarkan kemampuan berfikir HOTS, (b) Perumusun perencanaan model pembelajaran, (c) Perumusan penilaian pembelajaran berfikir HOTS dan (d) Mendesain pembelajaran yang berorientasi HOTS merupakan hal yang dianggap sulit oleh guru ekonomi akuntansi di Provinsi Riau. Sedangkan (a) Perumusan Indikator berdasarkan KI dan KD, (b) Perumusan tujuan pembelajaran, (c) Perumusan dan pemilihan materi ajar dan (d) Persiapan/pemilihan media pembelajaran merupakan hal yang cukup sulit oleh guru se ekonomi akuntansi di Provinsi Riau.

Sedangkan dari dimensi pelaksanaan dapat dijelaskan bahwa dari 8 subindikator yang ditanyakan kepada guru ekonomi akuntansi se Privinsi Riau 5 diataranya masuk dalam kategori "sulit" yaitu (1) Penerapan 5M dalam proses pembelajaran, (2) Merancang media untuk pembelajara 5M, (3) Mencari dan Penerapan model pembelajaran, (4) Penggunaan media belajar cetak/elektronik dan (5) Mengajak siswa untuk berfikir tingkat tinggi. Sedangkan 3 subindikator dinyatan "cukup sulit" yaitu (1) Penyampaian bahan ajar, (2) Pengelolaan kelas dan (3) Mengajak siswa untuk aktif.

Bermula dari perencanaan, kalau perencanaannya bermasalah tentu juga akan sampai pada pelasanaanya juga akan bermasalah. Pada K13 pendekatan pembelajaran yang disarankan adalh Pendekatan Saintifik. Pendekatan saintifik disaran untuk mencapai tujuan pembelajaran berdasarkan HOTS, sehingga guru terlebih dahulu harus paham tentang tujuan yang dibuat sehingga pendekatan saintifik dapat dengan mudah dilaksanakan.

Dimensi penilaian terlihat bahwa dari 8 sub indicator yang di tanyakan kepafa responden dua berada pada kategori "sangat sulit" yaitu (1) penilaian afektif dan (2) mengukur kemampuan berdasarkan HOTS sedang 6 lainya berada pada kategori "sulit" yaitu (1) Penilaian kognitif, (2) Penilaian psikomotorik, (3) Menilai secara individu/kelompok, (4) Menilai secara detail lengkap dan meyeluruh, (5) Mengolah/merekapitulasi nilai dan (6) Mengisi daftar penilaian.

Menilai sikap dan menilai berdasarkan HOTS merupakan dua sub incator yang sangat sulit dilakukan guru-guru ekonomi akuntansi. Hal ini juga tidak terlepas dari dimensi perencanaan, kalau sudah mengalami kesulitan pada saat merencanakan jelas akan terpapar sampai pada dimensi evaluasi. 


\section{Simpulan dan saran}

Umumnya di provinsi Riau guru ekonomi akuntansi berada pada kategori "sulit", seperti terlihat pada kategori perencanaan 9 dari 11 kabupaten/kota berada pada kategori "sulit" sedang satu berada pada kategori "sulit sekali" yaitu kabapaten Indragiri Hulu" dan satu kabupaten/kota berada pada kategori "cukup sulit" yaitu Pekanbaru dan yang berada pada kategori "tidak sulit" adalah "rokan hilir". Dimensi perencanaan, pembuatan RPP berdasarkan silabus merupakan hal yang sangat sulit bagi guru ekonomi akuntansi dan a) merumuskan indicator dan tujuan berdasarkan kemampuan berfikir HOTS, (b) Perumusun perencanaan model pembelajaran, (c) Perumusan penilaian pembelajaran berfikir HOTS dan (d) Mendesain pembelajaran yang berorientasi HOTS merupakan hal yang dianggap sulit oleh guru ekonomi akuntansi. Sedangkan (a) Perumusan Indikator berdasarkan KI dan KD, (b) Perumusan tujuan pembelajaran, (c) Perumusan dan pemilihan materi ajar dan (d) Persiapan/pemilihan media pembelajaran merupakan hal yang cukup sulit oleh guru se ekonomi akuntansi di Provinsi Riau. Dimensi pelaksanaan yang masuk dalam kategori "sulit" yaitu (1) Penerapan 5M dalam proses pembelajaran, (2) Merancang media untuk pembelajara 5M, (3) Mencari dan Penerapan model pembelajaran, (4) Penggunaan media belajar cetak/elektronik dan (5) Mengajak siswa untuk berfikir tingkat tinggi. Sedangkan 3 subindikator dinyatan "cukup sulit" yaitu (1) Penyampaian bahan ajar, (2) Pengelolaan kelas dan (3) Mengajak siswa untuk aktif. Dimensi penilaian berada pada kategori "sangat sulit" yaitu (1) penilaian afektif dan (2) mengukur kemampuan berdasarkan HOTS sedang 6 lainya berada pada kategori "sulit" yaitu (1) Penilaian kognitif, (2) Penilaian psikomotorik, (3) Menilai secara individu/kelompok, (4) Menilai secara detail lengkap dan meyeluruh, (5) Mengolah/merekapitulasi nilai dan (6) Mengisi daftar penilaian.

\section{Daftar Rujukan}

Anas Sudijono, 2008.Pengantar Statistik Pendidikan. Jakarta: PT Raja Grafindo Persada.

Asep Jihad dan Abdul Haris. 2008. Evaluasi Pembelajaran. Jakarta: Multi Press.

Benny A. Pribadi. 2009. Model Sistem pembelajaran. Jakarta: Dian Rakyat.

Endang Mulyani. 2013. Pembelajaran Scientific dalam Kurikulum 2013. Yogyakarta: Fakultas EkonomiUniversitas Negeri Yogyakarta.

Farida Yusuf Tayibnapis. 2008. Evaluasi Program dan Instrumen Evaluasi Dan Program Pendidikan Dan Penelitian. Jakarta: Rineka Cipta.

H. Dakir. 2004. Perencanaan dan Pengembangan Kurikulum. Jakarta: Rineka Cipta.

Hamid Darmadi. 2011. Metode Penelitian Pendidikan. Bandung: Alfabeta.

Kemendiknas. 2014. Struktur Kurikulum 2013. Diakses dari http://www.kemdiknas.go.id/kemdikbud/ujipublik-kurikulum-2013-4 pada 5 Desember 2018 pukul 12:12 WIB.

Margaret Puspitarini. 2014. Tiga Masalah Guru dalam Implementasi Kurikulum 2013.Artikel.Diakses dari http://news.okezone.com/read/2014/10/16/65/ 1052959/tiga-masalah-gurudalamimplementasi-kurikulum-2013 pada tanggal 27 Februari 2018 pukul 14:53 WIB.

Martinis Yamin. 2002. Belajar dan pembelajaran. Jakarta: Rineka Cipta.

Mulyasa. 2009. Menjadi Guru Profesional. Bandung: PT Remaja Rosdakarya.

Mulyasa. 2015. Pengembangan dan Implementasi Kurikulum 2013. Bandung: PT.Remaja Rosdakarya

Nana Syaodih Sukmadinata.2009. Pengembangan Kurikulum Teori dan Praktek. Bandung: PT Remaja Rosdakarya. Neti Budiawati. Pengembangan Silabus dan RPP Mata Pelajaran Ekonomi SMA/SMK.Jurnal.Diakses dari http://file.upi.edu/Direktori/ FPEB/PRODI. EKONOMI DAN KOPERA SI/196302211987032NETI_BUDIWATI/FILOSOFI_PEMBELAJARAN_EKONOMI_SMA.pdfpada tanggal 4 Januari 2019 pukul 15:30 WIB.

Oemar Hamalik. 2011. Kurikulum dan pembelajaran. Jakarta: PT Bumi Aksara.

Rusman. 2011. Model-model Pembelajaran: Mengembangkan Profesionalisme Guru. Jakarta: PT RajaGrafindo Persada.

Sholeh Hidayat. 2013. Pengembangan Kurikulum Baru. Bandung: PT Remaja Rosdakarya.

Sudaryono. 2012. Dasar-dasar Evaluasi Pembelajarran. Yogyakarta: Graha Ilmu.

Suharsimi Arikunto. 2010. Prosedur Penilian Suatu Pendekatan Praktek. Jakarta: Rineka Cipta.

Zainal Arifin. 2013. Evaluasi Pembelajaran. Bandung: PT. Remaja Rosdakarya. 